\title{
Variations in mercury and other trace elements contents in soil and in vine leaves from the Almadén Hg-mining district
}

\author{
Jose-Angel Amorós • José María Esbrí • \\ Francisco-Jesús García-Navarro • Caridad Pérez-de-los-Reyes • \\ Sandra Bravo • Begoña Villaseñor • Pablo Higueras
}

Received: 29 July 2013 / Accepted: 20 September 2013 / Published online: 8 October 2013

(C) Springer-Verlag Berlin Heidelberg 2013

\begin{abstract}
Purpose Vines (Vitis vinifera, L.) are a very important agricultural resource for Spain in general and for the Castilla-La Mancha region in particular, providing important productions of wines. Grapes and raisins are used for direct consumption too. In this work, we study analytical constraints regarding metallic trace elements uptake, focusing on $\mathrm{Hg}$, from vines growing in the Almadén mercury mining district, the world's largest producer of this element, inactive nowadays.

Materials and methods The study started with the analysis of these metals in soils and sets of vines leaves from seven sites located at different distances from the Almadén Hg mine. The samples of soils were dried at ambient temperature for 1 week. They were then sifted $(<2 \mathrm{~mm})$ and were stored for subsequent analysis. The leaves were dried and the leaf blade and petiole were separated. About $2 \mathrm{~g}$ of each sample were hand milled and analyzed using the same fluorescence spectrometer. Total mercury in soils and vine leaves were determined using a Lumex RA-915+ device, an atomic absorption spectrometer with a pyrolysis unit (RP-91c).

Results and discussion Results show significant correlations between soil and leaves contents for total and organic mercury ( $\mathrm{R}=0.934$ and 0.984 , respectively). $\mathrm{Hg}$ contents range in soil from 2,376 to $0.04 \mathrm{mg} / \mathrm{kg}$ in non-polluted places. For the
\end{abstract}

Responsible editor: Jaume Bech

J.-A. Amorós $(\bowtie) \cdot$ J. M. Esbrí • F.-J. García-Navarro •

C. Pérez-de-los-Reyes $\cdot$ S. Bravo $\cdot$ B. Villaseñor $\cdot$ P. Higueras

Instituto de Geología Aplicada, Universidad de Castilla-La Mancha,

Pl. Manuel Meca 1, Almadén, 13400 Ciudad Real, Spain

e-mail: joseangel.amoros@uclm.es

J.-A. Amorós · F.-J. García-Navarro · C. Pérez-de-los-Reyes •

$\mathrm{S}$. Bravo $\cdot$ B. Villaseñor

Escuela de Ingenieros Agrónomos de Ciudad Real, Universidad de

Castilla-La Mancha, Ronda de Calatrava 7, 13071 Ciudad Real, Spain organic fraction, the range varies between 197.49 and $3.15 \mathrm{mg} / \mathrm{kg}$. Total $\mathrm{Hg}$ contents measured in leaves were from $5.14 \mathrm{mg} / \mathrm{kg}$ (close to dump zone of the mine) to $0.03 \mathrm{mg} / \mathrm{kg}$ in the proximity of Carrión de Calatrava, located some $100 \mathrm{~km}$ away from Almadén. Mercury reaches maximum in the proximity of known sources of the element: the mining and/or metallurgical areas of Almadén and Almadenejos.

Conclusions Soils from the study area contain normal contents in trace metals, and these are conditioned by the local geology or urban locations of the area. Trace metals contents in leaves do not show a relationship with soil contents, possibly due to the low bioavailability of these elements in the soils investigated. Mercury is, as expected for this area, an exception to this trend, with very high concentrations that reach maximum values in the proximity of the known sources of the element: the proximity of mining and/or metallurgical areas in Almadén and Almadenejos.

Keywords Bioaccumulation · Metallic trace element . Pollution

\section{Introduction}

The Almadén mercury mining district, located in SouthCentral Spain, Castilla-La Mancha region (Fig. 1), corresponds to the biggest mercury geochemical anomaly in the world, having yielded almost one-third of total production of the element (Hernández et al. 1999). Description of the geological characters of the area can be found in Saupé (1990) and Hernández et al. (1999), among others, meanwhile Lindberg et al. (1979), Huckabee et al. (1983), Higueras et al. (2003), Millán et al. (2004, 2006, 2011), Molina et al. (2006), Moreno-Jiménez et al. (2006) and Martínez-Coronado et al. (2011) describe environmental concerns for mercury in the area including local soil/plant relationships. 
Fig. 1 Location of plots M1 to M6 in Almadén mining district and M7 in Carrión de Calatrava (non contaminated zone)

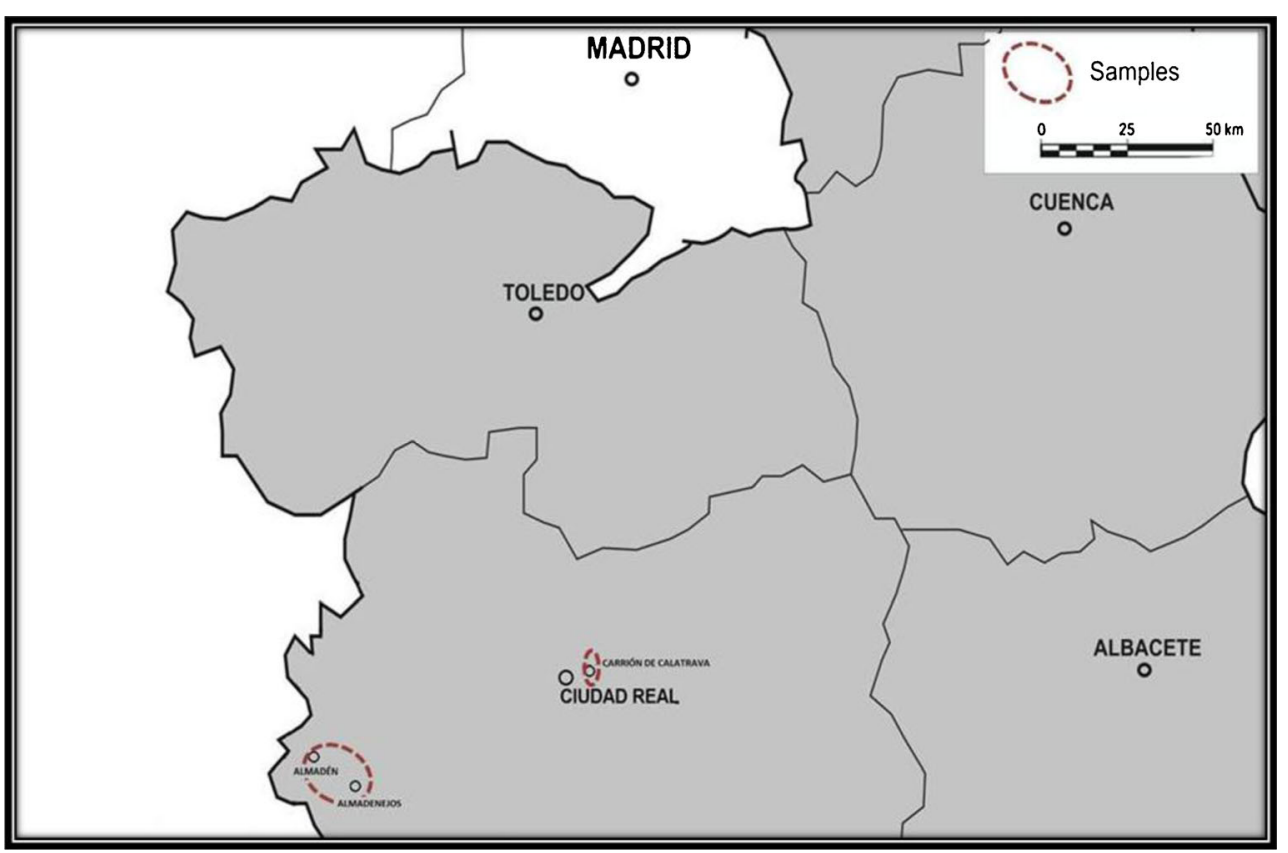

The cultivation of the grapevine in Castilla-La Mancha is of great national and global importance due to the large area in question (467.690 ha according to official data, Ministery of agriculture, feeding and environmental). This importance is reflected in the traditions and in the economic impact that the wine sector has on the regional economy (Pillet 2007). Eleven appellations of origin and other quality control requirements for the wine serve to increase the added value of the product. The factors outlined above demonstrate the importance of the 'terroir' in the valuation of the wines (Hugget 2006). The soil is one of the most important components of the 'terroir' (together with the climate and the cultural practises). It is therefore of interest to ascertain the influence of the soil and to obtain analytical evidence.

Several studies have been carried out on Mediterranean regions and areas of influence to investigate soil origins, parent materials and their characteristics (Carlevalis et al. 1992; Amorós et al. 2010). The study of geochemical soil composition provides information, along with other complementary data, about fertility and the availability of nutrients for plants. Major elements provide information about total structural components and potential nutrients (Wild 1992; Lanyon et al. 2004; White 2009). On the other hand, contents of trace elements give an insight into the geochemical origin (García-Navarro et al. 2011) and potential toxicities (Patra and Sharma 2000; Conde et al. 2009) of the soil.

The metabolism of trace elements in plants has been widely studied (Wild 1992; Kabata-Pendias 2001). However, every plant-soil system has to be specifically studied, since the behaviour could differ depending on the elements present in a particular system (Kabata-Pendias 2001; Molina et al. 2006), as well as on the particular chemical form of the element in the soil. In all previously studied cases, plant composition (leaves, fruits, juices, tubers, etc.) always reflected the chemical properties from the cultivation environment (Bargagli 1995; Kabata-Pendias 2001; Vavoulidou et al. 2004; Zeiner et al. 2005; Higueras et al. 2011).

At present, it is well known that 17 trace elements (Al, B, $\mathrm{Br}, \mathrm{Cl}, \mathrm{Co}, \mathrm{Cu}, \mathrm{F}, \mathrm{Fe}, \mathrm{I}, \mathrm{Mn}, \mathrm{Mo}, \mathrm{Ni}, \mathrm{Rb}, \mathrm{Si}, \mathrm{Ti}, \mathrm{V}$ and $\mathrm{Zn}$ ) are essential for plants; it has been proved that some of them are

Table 1 Metals contents in soils studied (Fe in $\mathrm{g} / \mathrm{kg}$ and $\mathrm{Cu}, \mathrm{Zn}$ and $\mathrm{Pb}$ in $\mathrm{mg} / \mathrm{kg}$ ) (M1 to M7 are the name of samples; CLM, Castilla La Mancha)

\begin{tabular}{|c|c|c|c|c|c|c|c|c|c|c|}
\hline & M1 & M2 & M3 & M4 & M5 & M6 & M7 & $\bar{x}$ & $\begin{array}{l}\text { Levels of CLM } \\
\text { (1) (Amorós et al. 2011) } \\
\text { (2) (Jiménez-Ballesta et al. 2010) }\end{array}$ & $\begin{array}{l}\text { Levels in olive leaf } \\
\text { (Higueras et al. 2011) }\end{array}$ \\
\hline $\mathrm{Fe}$ & 48.50 & 43.28 & 45.83 & 44.35 & 56.16 & 47.49 & 21.53 & 43.88 & $38.69^{(1)}$ & - \\
\hline $\mathrm{Cu}$ & 27.10 & 35.30 & 27.50 & 20.60 & 39.50 & 10.60 & 14.70 & 25.04 & $27.00^{(2)}$ & 32.40 \\
\hline $\mathrm{Zn}$ & 92.30 & 120.80 & 103.80 & 85.80 & 148.80 & 51.60 & 33.80 & 90.99 & $86.50^{(2)}$ & 85.23 \\
\hline $\mathrm{Pb}$ & 67.80 & 30.60 & 34.40 & 35.60 & 122.90 & 17.20 & 16.70 & 46.46 & $44.20^{(2)}$ & 47.81 \\
\hline
\end{tabular}


Table 2 Metals contents in vine leaves studied $(\mathrm{Fe}$ in $\mathrm{g} / \mathrm{kg}$ and $\mathrm{Cu}$, $\mathrm{Zn}$ and $\mathrm{Pb}$ in $\mathrm{mg} / \mathrm{kg}$ ) (M1 to $\mathrm{M} 7$ are the name of samples)

\begin{tabular}{rrrrrrrrrr}
\hline & M1 & M2 & M3 & M4 & \multicolumn{1}{l}{ M5 } & M6 & M7 & \multicolumn{1}{c}{} & $\begin{array}{l}\text { Levels in olive leaf } \\
\text { (Higueras et al. 2011) }\end{array}$ \\
\hline $\mathrm{Fe}$ & 0.18 & 0.14 & 0.25 & 0.22 & 0.16 & 0.14 & 0.11 & 0.17 & 0.01 \\
$\mathrm{Cu}$ & 0.00 & 0.70 & 0.50 & 1.10 & 12.95 & 7.47 & 14.27 & 5.28 & \multicolumn{1}{c}{-} \\
$\mathrm{Zn}$ & 19.20 & 18.20 & 17.80 & 18.20 & 46.75 & 47.00 & 22.77 & 27.13 & 21.10 \\
$\mathrm{~Pb}$ & 3.40 & 2.80 & 2.70 & 3.20 & 3.65 & 12.17 & 4.90 & 4.69 & 3.80 \\
\hline
\end{tabular}

necessary only for some species, and others have just stimulating effects for plant growing, but their functions have not been yet identified (Wild 1992). Some elements seem to be not needed at all, and can be toxic to plants: $\mathrm{Hg}, \mathrm{Ni}, \mathrm{Pb}, \mathrm{Co}$ and $\mathrm{Cd}$, mainly.

In this paper, we study the distribution of mercury and some metals ( $\mathrm{Fe}, \mathrm{Cu}, \mathrm{Zn}$ and $\mathrm{Pb}$ in soil and leaf) in vine leaves of contaminated area and surroundings and in an area $100 \mathrm{~km}$ from the mine, and their soils, in order to assess the particular behaviour of these elements in this plant. Moreover, we compare the $\mathrm{Hg}$ uptake with the uptake of other trace elements in order to better explain the absorption behaviour for this element in this plant.

\section{Materials and methods}

Sampling sites for this study were selected as a transect from the main mercury pollution sources and progressively away from them, up to a locality sited some $100 \mathrm{~km}$ away from Almadén (Fig. 1).

The samples of soils were described and collected according with FAO guidelines (2006) form surface horizons, under the plant. Each sample was dried at ambient temperature for 1 week. They were then sieved $(<2 \mathrm{~mm})$ and were stored for subsequent analysis. The leaves were collected after harvest and from the middle part of the shoot. After, the samples were dried at $105{ }^{\circ} \mathrm{C}$ and the leaf blade and petiole were separated. About $2 \mathrm{~g}$ of each sample were hand milled and analyzed using the same fluorescence spectrometer.

Total mercury in soils and vine leaves were determined using a Lumex RA-915+ device, an atomic absorption spectrometer with a pyrolysis unit (RP-91c), where sample matrix is destructed and mercury atoms are counted on an atomic absorption spectroscopy with Zeeman effect to avoid matrix effect on quantification (Molina et al. 2006). Bioavailable mercury was performed according to the methodology reported by Perez et al. (2008). Briefly, this methodology consists on lixiviate extraction with $0.5 \mathrm{M} \mathrm{HCl}$ for $1 \mathrm{~h}$ with magnetic stirring. The solid/water ratio was $1 \mathrm{~g}: 20 \mathrm{ml}$. After centrifugation at 3,500 rpm for $10 \mathrm{~min}$, the extracts were filtered with a $0.22 \mu \mathrm{m}$ filter (Millex-GS, Millipore) and analyzed by AAS (AMA 254).
The other metals were determined by X-ray fluorescence, using a calibration for trace elements in a sequential spectrometer (Philips, model Magix Pro) with a $4 \mathrm{~kW}$ light element super sharp RH target end window X-ray tube, a set of analyzer crystals of LiF220, LiF200, Ge, PE y PX1 and with a flow and a sealed proportional detector in tandem, plus a scintillation detector in parallel. The analysis of the samples was carried out as fused glass discs and using a specific calibration for soils and one adapted from fundamental parameters for plants. The quality control was evaluated by duplicate analysis of certified reference samples (BCR 62, SMR 1573, SMR 1515).

\section{Results and discussion}

\subsection{Metal contents in soils}

The analytical results for metal contents in the analyzed soils are shown in Table 1, along with average reference levels for Castilla-La Mancha region (Jiménez-Ballesta et al. 2010) and results of other study about Almadén (Higueras et al. 2011). Average of the measured concentrations can be considered as normal contents for non-contaminated rural areas, with values close to those reported by Jiménez-Ballesta (2010) and Higueras et al. (2011). However, some samples show concentrations above these reference values; $\mathrm{Cu}$ and $\mathrm{Zn}$ have concentrations above their reference levels for some of the analyzed soils, particularly in proximity to the mine (sites 1,2 and 3 ) and site 5 close to Almadenejos. And $\mathrm{Pb}$ is above their

Table 3 Total mercury contents in soils and vine leaves studied $(\mathrm{mg} / \mathrm{kg})$ and Bioavailable (Bioav.) Hg in soils (ng/g) (M1 to M7 are the name of samples)

\begin{tabular}{lrrl}
\hline & Total Hg in soil & Bioav. Hg in soil & Hg in leaves \\
\hline M1 & 162.33 & 23.52 & 0.80 \\
M2 & 2376.67 & 197.49 & 5.14 \\
M3 & 544.00 & 80.91 & 2.19 \\
M4 & 162.00 & 18.92 & 1.17 \\
M5 & 105.33 & 53.05 & 2.03 \\
M6 & 0.04 & 4.89 & 0.06 \\
M7 & 0.04 & 3.15 & 0.03 \\
\hline
\end{tabular}




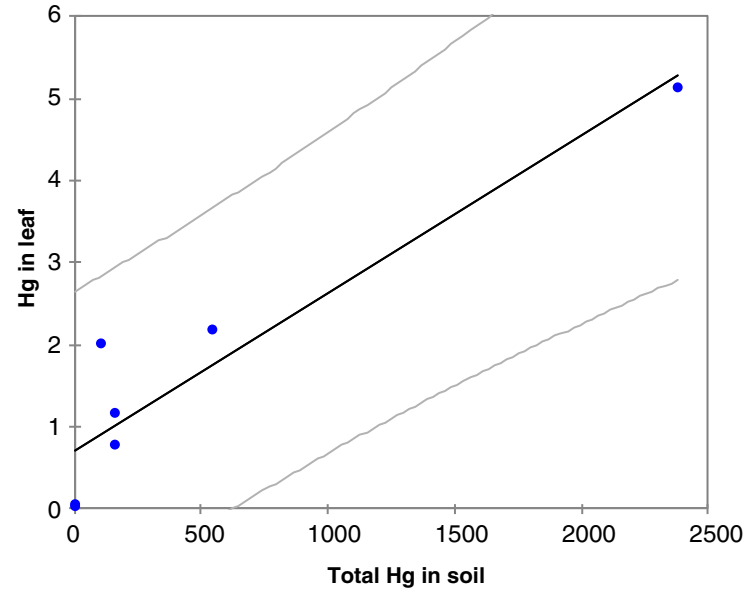

Fig. 2 Soil/leaf relationship for total and organic mercury

references for sites 1 and 5 too. Fe is above levels of Sparks (2003), except in sample 7.

$\mathrm{Cu}$ and $\mathrm{Zn}$ are elements that are usually linked to periurban pollution (Martínez-Coronado et al. 2011). Similar soils have been studied in nearby areas by Amorós et al. (2010, 2011), and they often show a slightly acidic $\mathrm{pH}$ and relatively high clay content; these studies showed that many metallic elements are straightly linked to the clay fraction: $\mathrm{Fe}, \mathrm{Al}, \mathrm{V}, \mathrm{Cr}$, $\mathrm{Co}, \mathrm{Ni}, \mathrm{Cu}, \mathrm{Zn}$ and $\mathrm{Pb}$.

\subsection{Metal contents in leaves}

Average leaf contents for trace metals are shown in Table 2 along with reference values by Higueras et al. (2011). The $\mathrm{Pb}$ content $(4.69 \mathrm{mg} / \mathrm{kg}$ ) is below world normal values (KabataPendias 2001) but above contents reported by Higueras et al. (2011). Fe values $(0.17 \mathrm{mg} / \mathrm{kg})$ are above world normal values (Wild 1992) and levels in Almadén by Higueras et al. (2011). $\mathrm{Zn}$ levels $(27.13 \mathrm{mg} / \mathrm{kg}$ ) are above the world average (Barranco et al. 2004) and values reported by Higueras et al. (2011). Values for $\mathrm{Cu}$ were not found in the literature.

\subsection{Soil-leaf relationships}

The values obtained for correlation between soil and leaf contents did not indicate significant correlations in any element. The biological absorption coefficient is calculated as the ratio between the concentration of any studied element in the plant and the concentration found in the corresponding soil (BAC $=[$ leaf blade]/[soil] $)$. For our data, all BAC is well lower than the general level for the world (Kabata-Pendias 2001).

\subsection{Mercury}

Table 3 displays the mercury contents obtained from the soils and vines from contaminated and uncontaminated areas.

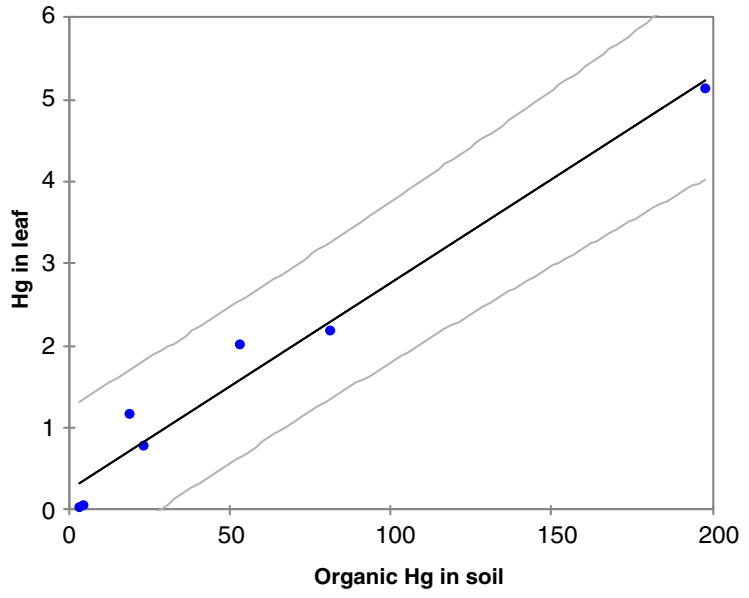

Results in the samples from the evidently contaminated areas are higher than in the samples from uncontaminated areas.

Total mercury contents in soil from $2,376 \mathrm{mg} / \mathrm{kg}$ in contaminated areas to $0.04 \mathrm{mg} / \mathrm{kg}$ in non-polluted places. In the case of organic fraction, the range varies between 197.49 and $3.15 \mathrm{mg} / \mathrm{kg}$.

The mercury content in leaves ranges from $0.03 \mathrm{mg} / \mathrm{kg}$ in leaves collected from the uncontaminated sites to $5.14 \mathrm{mg} / \mathrm{kg}$ for leaves from the area in proximity to the Almadén mine. Despite the fact that levels in some cases are above the $3 \mathrm{mg} /$ $\mathrm{kg}$ value suggested as toxic by Kabata-Pendias (2001), visual symptoms of toxicity were not observed.

The soil/leaf relationship for mercury was of particular interest in this study. Mercury uptake from the soil depends to a large degree on the chemical species available in the soil, particularly in mining areas, where cinnabar is the main mercury form present in the soil (Llanos et al. 2011). As mentioned before, correlation between leaf contents and total mercury in the soil is high $(\mathrm{R}=0.934)$, but if we take into account the bioavailable mercury contents, the correlation is higher $(\mathrm{R}=0.984)$ than in the previous case (Fig. 2).

\section{Conclusions}

The following main conclusions of this study are outlined below:

1. Soils from the study area, centred in the Almadén mercury mining district, shown normal contents in trace metals, and these are conditioned by the local geology or urban locations of the area. Nevertheless, some samples show concentrations above these reference values, mainly in proximity to the mine (sites 1, 2 and 3 ) and site 5 close to Almadenejos.

2. In leaves, the $\mathrm{Fe}, \mathrm{Zn}$ and $\mathrm{Pb}$ content is over the values by Higueras et al. (2011). Values for $\mathrm{Cu}$ were not found in the literature and it is highly influenced by pesticide treatments. 
3. Trace metals contents in leaves do not show a relationship with soil contents, possibly due to the low bioavailability of these elements in the soils investigated. In fact, all BAC is lower than the general level for the world (Kabata-Pendias 2001).

4. Mercury is, as expected for this area, an exception to this trend, with very high concentrations that reach maximum values in the proximity of the known sources of the element: the proximity of mining and/or metallurgical areas in Almadén and Almadenejos. Mercury is also an exception and has high contents, well above published toxic levels, which do not correlate with total $\mathrm{Hg}$ contents in the soil but do show a strong correlation with bioavailable mercury. The soil/leaf relationship for total mercury was high $(\mathrm{R}=0.934)$ and higher $(\mathrm{R}=0.984)$ for bioavailable mercury.

Acknowledgments This work has been funded by the "Ministry of Economy and Competitiveness, Spanish Government", project CTM2012-33918 and "Junta de Comunidades de Castilla-La Mancha", project PPII10-0063-8230.

\section{References}

Amorós JA, Pérez-de-los-Reyes C, García-Navarro FJ, Sánchez CJ, Jiménez-Ballesta R (2010) Description of red soils in a semiarid climate and evaluation for vineyard (Vitis vinifera, L.) use. Fresenius Environ Bull 19:1199-1207

Amorós JA, Pérez-de-los-Reyes C, García-Navarro FJ, Sánchez CJ, García R, Jiménez-Ballesta R (2011) Trace elements distribution in red soils under semiarid Mediterranean environment. Int J Geosci 2: 84-97. doi:10.4236/ijg.2011.22009

Bargagli R (1995) The elemental composition of vegetation and the possible incidence of soil contamination of samples. Sci Total Environ 176:121-128

Barranco D, Fernández Escobar R, Rallo Romers L (2004) El cultivo del olivo. Editorial Mundiprensa. $5^{\mathrm{a}}$ edición. $800 \mathrm{pp}$

Carlevalis JJ, De La Horra JL, Serrano F, Rodriguez J (1992) La fertilidad de los principales suelos agrícolas de la zona oriental de la provincia de Ciudad Real. La Mancha y Campo de Montiel. C.S.I.C. and J.J.C.C. Castilla-La Mancha, Vol. 1. Madrid. 294 pp

Conde P, Martín J, De la Horra J, Jiménez-Ballesta R (2009) Trace elements contents in different soils of a semiarid Mediterranean environment: Castilla-La Mancha, Spain. Fresenius Environ Bull 18:858-867

FAO (2006) Guidelines for Soil Description, 4th edn. AO/UNESCO, Rome

García-Navarro F, Amorós JA, Sánchez C, Jiménez-Ballesta R (2011) Red soil geochemistry in a semiarid Mediterranean environment and its suitability for vineyards. Environ Geochem Health 33:279-289

Hernández A, Jébrak M, Higueras P, Oyarzun R, Morata D, Munhá J (1999) The Almadén mercury mining district, Spain. Miner Deposita 34:539-548

Higueras P, Oyarzun R, Biester H, Lillo J, Lorenzo S (2003) A first insight into mercury distribution and speciation in soils from the Almadén mining district, Spain. J Geochem Explor 80:95-104

Higueras P, Amorós JA, Esbrí JM, García-Navarro FJ, Pérez-delos-Reyes C, Moreno G (2011) Time and space variations in mercury and other trace elements contents in olive-tree leaves from the Almadén $\mathrm{Hg}$ mining district. J Geochem Explor 123:143-151
Huckabee JW, Sanz Diaz F, Janzen SA, Solomon J (1983) Distribution of mercury in vegetation at Almaden, Spain. Environ Pollut Ser A Ecol Biol 30:211-224

Hugget JM (2006) "Geology and wine: a review". Proceedings of Geologists' Association, 117:236-247

Jiménez-Ballesta R, Conde-Bueno P, Martín-Rubí JA, García-Jiménez R (2010) Pedo-geochemical baseline contents levels and soil quality reference values of trace elements in soils from the Mediterranean (Castilla La Mancha, Spain). Centre Eur J Geosci 2:441-454

Kabata-Pendias A (2001) Trace Elements in Soils and Plants, 3rd edn. CRC Press, Boca Raton, USA, 413 pp

Lanyon D, Cass A, Hansen D (2004) The Effect of Soil Properties on Vine Performance CSIRO Land and Water Technical Report 34/04. Glen Osmond, Australia, $54 \mathrm{pp}$

Lindberg SE, Jackson DR, Huckabee JW (1979) Atmospheric emission and plant uptake of mercury from agricultural soils near the Almaden mercury mine. J Environ Qual 8:572-578

Llanos W, Kocman D, Higueras P, Horvat M (2011) Mercury emissions and dispersion models from soils contaminated by cinnabar mining and metallurgy. J Environ Monitor, in press. doi: 10.1039/ C1EM10694E

Martínez-Coronado A, Oyarzun R, Esbrí JM, Llanos W, Higueras P (2011) Sampling high to extremely high $\mathrm{Hg}$ concentrations at the Cerco de Almadenejos, Almadén mining district (Spain): the old metallurgical precinct (1794 to $1861 \mathrm{AD}$ ) and surrounding areas. J Geochem Explor 109:70-77

Millán R, Gamarra R, Schmid T, Vera R, Sierra MJ, Quejido AJ, Sánchez DM, Fernández M (2004) Mercury content in natural vegetation of three plots in the mining area of Almadén (Spain). RMZ-Mater Geoenviron 51:155-158

Millán R, Gamarra R, Schmid T, Sierra MJ, Quejido AJ, Sánchez DM, Cardona AI, Fernández M, Vera R (2006) Mercury content in vegetation and soils of the Almadén mining area (Spain). Sci Total Environ 368:79-87

Millan R, Schmid T, Sierra MJ, Carrasco-Gil S, Villadóniga M, Rico C, Ledesma DMS, Puente FJD (2011) Spatial variation of biological and pedological properties in an area affected by a metallurgical mercury plant: Almadenejos (Spain). Appl Geochem 26:174-181

Molina JA, Oyarzun R, Esbrí JM, Higueras P (2006) Mercury accumulation in soils and plants in the Almadén mining district, Spain: one of the most contaminated sites on earth. Environ Geochem Health 28:487-498

Moreno-Jiménez E, Gamarra R, Carpena-Ruiz RO, Millán R, Peñalosa JM, Esteban E (2006) Mercury bioaccumulation and phytotoxicity in two wild plant species of Almadén area. Chemosphere 63:19691973

Patra M, Sharma A (2000) Mercury toxicity in plants. Bot Rev 66:379422

Pérez G, López-Mesas M, Valiente M (2008) Assessment of heavy metals remobilization by fractionation: comparison of leaching tests applied to roadside sediments. Environ Sci Technol 42:2309-2315

Pillet F (2007) Geografía de Castilla-La Mancha. I.S.B.N.n': 978-84-935656-0-2. $344 \mathrm{pp}$

Saupé F (1990) Geology of the Almadén mercury deposit, province of Ciudad Real, Spain. Econ Geol 85:482-510

Sparks DL (2003) Environmental Soil Chemistry. Editorial Elsevier

Vavoulidou E, Avramides EJ, Papadopoulos P, Dimirkou A (2004) Trace metals in different crop-cultivation systems in Greece. Water Air Soil Pollut: Focus 4:631-640

Wild A (1992) Condiciones del Suelo y el Desarrollo de las Plantas según Russell. Ed. Mundiprensa, Madrid, 1045

White RE (2009) Understanding Vineyard Soils. Oxford University Press. $230 \mathrm{pp}$

Zeiner M, Steffan I, Juranovic I (2005) Determination of trace elements in olive oil by ICP-AES and ETA-AAS: a pilot study on the geographical characterization. Microchem J 81:171-176 